\title{
Az Alkotmánybíróság fontosabb döntései 2019. július 1-je és december 31-e között
}

\section{SZABÓ ATTILA}

Az Alkotmánybiróság 2019 második félévében 253 döntést hozott, amelyek közül 65 érdemi határozat volt. Az Alkotmánybiróság normakontrollos hatásköreiben négy esetben mondta ki jogszabály alaptörvény-ellenességét. A vizsgált időszakban négy esetben mondott ki jogalkotói mulasztásban megnyilvánuló alaptörvény-ellenességet és három esetben alkotmányos követelményt. Az Alkotmánybíróság legtöbbet gyakorolt hatásköre továbbra is az alkotmányjogipanasz-eljárás, amelyek közül továbbra is kiemelkedik a bírói itéletekkel szemben elöterjesztett panasz. Ebben a hatáskörében eljárva a második félévben tizenhat bírói döntést semmisitett meg.

A cikk hat fontosabb döntést foglal össze a vizsgált idöszakból. Az Alkotmánybiróság a sajtó szabadsága és a képmásvédelem szempontjából fontos elveket rögzitett a 23/2019. (VII. 18.) AB határozatban. A magánélet védelméhez való jog és a sajtószabadság ütközésének kérdésében a 26/2019. (VII. 23.) AB határozat is a sajtó szabadságát védi, a közszereplökre vonatkozó korábban kidolgozott mércét kiterjesztve a közhatalommal nem rendelkezö, de politikai életre hatással bíró személyekre. A 20/2019. (VI. 26.) AB határozatban az Alkotmánybíróság mulasztásban megnyilvánuló alaptörvény-ellenesség megállapítása mellett egy jogállami büntető eljárásjogi garancia érvényesitésére hivta fel a jogalkotót. A 29/2019. (XI. 4.) AB határozatban az Alkotmánybíróság a közszereplők bírálhatósága szempontjából fontos, a szólásszabadságot védö határozatot hozott. Az Alkotmánybiróság a 3294/2019. (XI. 18.) AB határozatban a fegyelmi eljárás megszüntetése miatt visszatartott illetmény ügyében született diszkriminatív döntés miatt megsemmisitette a Kúria itéletét. A 34/2019. (XI. 29.) AB határozatban az Alkotmánybiróság megállapitotta az illetékekröl szóló törvény (Itv.) egy hatályon kívül helyezett rendelkezése alaptörvény-ellenességét, mert a diszkrimináció tilalmába ütközött.

\section{Certain Significant Decisions of the Constitutional Court between 1 July and 31 December 2019}

The Constitutional Court (hereinafter: CC) made 253 decisions in the second semester of 2019. From these, 65 decisions were on the merits. In the competences of norm control the CChas declared the unconstitutionality of four legal regulations, it declared three constitutional requirements and four legislative omissions. The mostly practiced competence of the CC is still 
the constitutional complaint procedure, mainly the one against judicial decisions. In its competence, the Court annulled sixteen judicial decisions in the second semester of 2019.

The Article summarises six significant decisions of the CC from the second semester of the year. The CC has established certain principles that are important from the viewpoint of the freedom of press and the protection of images [CC decision 23/2019. (VII. 18.) AB]. Also CC decision 26/2019. (VII. 23.) protects the freedom of press, and extends the measure used for the public persons also to the people who do not bear public power but still have some influence on political life. In CC decision 20/2019. (VI. 26.) the CC declared a legislative omission and called upon the lawmaker to ensure a criminal law procedural guarantee under the rule of law. CC decision 29/2019. (XI. 4.) has made an important decision protecting free speech and the criticism of public figures. CC decision 3294/2019. (XI. 18.) annulled a decision of the Curia (Supreme Court) which applied a legal regulation in a discriminatory manner in case of an officer whose disciplinary procedure was ceased. CC decision 34/2019. (XI. 29.) declared the unconstitutionality of a provision of the Act on Revenues as it violated the prohibition of discrimination.

\section{A)}

Az Alkotmánybíróság testületei (teljes ülése, illetve öttagú tanácsai) 2019 második félévében 253 döntést hoztak, amelyek közül 65 érdemi határozat, míg 187 - többnyire a befogadási eljárás során hozott - visszautasító végzés ${ }^{1}$. Az érdemi határozatok - az Alkotmánybíróság hatásköreire figyelemmel - a következők szerint oszlanak meg. Az Alkotmánybíróság a vizsgált időszakban, öt esetben utólagos normakontroll indítvány [az Alkotmánybíróságról szóló 2011. évi CLI. törvény (a továbbiakban: Abtv.) 24. \$-a] alapján (az országgyủlési képviselők egynegyedének indítványára) járt el. Az Abtv. 25. \$-a szerinti bírói kezdeményezés alapján tíz esetben hozott határozatot. Az Alkotmánybíróság legtöbbet gyakorolt hatáskörében, alkotmányjogipanaszeljárásban összesen 50 érdemi határozatot hozott, amelyből 30 - az Abtv. 27. \$-a alapján - bírói ítélettel szemben előterjesztett panasz volt, hat - az Abtv. 26. $\mathbb{S}(1)$ bekezdése szerinti - bírói ítéletben alkalmazott normával szemben előterjesztett panasz, négy pedig - az Abtv. 26. $\mathbb{S}(2)$ bekezdése szerinti - közvetlen panasz. Fentieken túl - az őszi önkormányzati választásokra tekintettel - választási, illetve népszavazási ügyben előterjesztett alkotmányjogi panaszokat is elbírált a testület.

A határozatokban megállapított jogkövetkezményeket tekintve az alábbi döntések születtek. Jogszabályi rendelkezés alaptörvény-ellenességének megállapítására és megsemmisitésére a második félévben három esetben került sor. Már hatályon kívül helyezett jogszabály alaptörvény-ellenességét egy esetben állapította meg

1 A statisztikai adatok alapját a 2019. július 1. és 2019. december 31. között az Alkotmánybíróság Határozatai című kiadványban, illetve a Magyar Közlönyben közzétett döntések adják. 
az Alkotmánybíróság. Bírói, illetve hatósági döntést alaptörvény-ellenesség miatt 16 esetben semmisített meg az Alkotmánybíróság. Két esetben a jogszabály alkalmazási tilalmát mondta ki. Mulasztásban megnyilvánuló alaptörvény-ellenességet négy ügyben állapított meg, három alkalommal állapított meg alkotmányos követelményt. Az indítványokat határozatban 47 esetben utasította el, 188 esetben pedig visszautasító végzéssel zárta le az eljárást.

A bírói döntések felülvizsgálatakor, azok megsemmisítése esetén a következő alapjogok védelme érdekében állapította meg az Alkotmánybíróság az alaptörvényellenességet a második félévben: emberi méltósághoz való jog, véleménynyilvánításhoz való jog, sajtószabadság, hátrányos megkülönböztetés tilalma, tisztességes eljáráshoz való jog, jogorvoslathoz való jog és a visszaható hatályú jogalkalmazás tilalma.

A testület normakontrollos hatáskörében eljárva, a jogszabály megsemmisítésekor az Alaptörvény B) cikk (1) bekezdésébe (jogállamiság, visszaható jogalkotás tilalma), a T) cikk (3) bekezdésébe (jogszabályi hierarchia), a XII. cikk (1) bekezdésébe (vállalkozáshoz való jog), valamint a XV. cikk (1) bekezdésébe (hátrányos megkülönböztetés tilalma) való ütközést állapította meg.

\section{B)}

Az alapjogok védelme és a magyar alkotmányjog dogmatikájának szempontjából, időrendi sorrendben, a következő döntések részletes ismertetése szükséges a 2019. év második félévének határozatai közül.

1. Közhatalmat gyakorló személy esetében a képmásvédelem csak akkor lehet a sajtószabadság valós korlátja, ha a képmás közzététele - a felismerhetővé váláson túlmutatóan - valamilyen alapjog sérelmét vagy más alkotmányos érték sérelmét okozza.

Az Alkotmánybíróság a 23/2019. (VII. 18.) AB határozatban a sajtó szabadsága és a képmásvédelem szempontjából fontos elveket rögzített.

1.1. Az indítványozó televíziós csatorna alkotmányjogi panaszában kérte, hogy az Alkotmánybíróság semmisítse meg a Fővárosi Ítélőtábla ítéletét. Az indítványra okot adó ügyben a Fővárosi Törvényszék ítéletében az indítványozót marasztalta és sérelemdíj fizetésére kötelezte. Az indítványozó televíziós csatorna a híradójában tudósított egy, a Kúria előtt folyó tárgyalásról, amelynek során a vádlott arcát kitakarta, de az őt kísérő büntetés-végrehajtási dolgozóét nem, így ő a képmása védelméhez füződő jogának megsértése miatt fordult bírósághoz. A Törvényszék megállapította, hogy a felperes a képmás nyilvánosságra hozatalához nem járult hozzá. Rámutatott, hogy nem minősül nyilvános közéleti eseménynek a tárgyalótermi jelenlét, és a felperes egyedi ábrázolása sem minősíthető tömegfelvételnek. Hivatkozott az ítélet arra, hogy sem a rendőrök, sem a büntetés-végrehajtási alkalmazottak nincsenek abban a helyzetben tevékenységük ellátása során, hogy a képkészítés ellen tiltakozzanak; öncélú ábrázolásuk jogsértő. 
Az indítványozó fellebbezése folytán a Fővárosi Îtélőtábla az elsőfokú döntést helybenhagyta. Indokolásban kitért arra, hogy az indítványozó a tájékoztatási kötelezettségének akként is eleget tehetett volna, hogy a felperest felismerhetően nem jeleníti meg. Az alperes olyan eseményről nem számolt be, ami miatt a felperes kifejezetten a tudósítás középpontjába került, a konkrét esetben tehát a képmáshoz való jog védelme megalapozta a sajtószabadság érvényesülésének a korlátozását.

1.2. Az indítványozó televíziós csatorna szerint a bíróság döntése ellentétes a véleménynyilvánítási szabadságot és sajtószabadságot biztosító alaptörvényi rendelkezésekkel.

1.3. Az Alkotmánybíróságnak abban az új alkotmányossági kérdésben kellett állást foglalnia, hogy a sajtószabadságra hivatkozással szabadon közzétehetö-e a közhatalmat gyakorló személy bírósági tárgyaláson készült képmása, azaz hozzáférhetővé tehetö-e olyan médiatartalom, amelyen egy bírósági tárgyaláson jelen lévő, közhatalmat gyakorló személy felismerhető.

1.4. A médiaszolgáltató alkotmányos jogát gyakorolja, amikor a közérdeklődésre számot tartó eseményekről tudósít. E szabadsága kiterjed annak meghatározására is, hogy mely eseményekről milyen részletességgel és tartalommal ad tájékoztatást. Amennyiben a sajtószabadság gyakorlása sérti más alapjogát vagy valamilyen alkotmányos célt, akkor az Alkotmánybíróságnak kell döntést hoznia arról, hogy a konkrét esetben a sajtószabadság gyakorlásának vagy az azt korlátozó célnak kell-e inkább teret engednie.

Az Alkotmánybíróság korábbi gyakorlata alapján valamely közhatalmat gyakorló személy képmásának sajtó általi közzététele esetén négy szempontot kell vizsgálnia. Egyrészt, hogy a képmás közzététele összefügg-e az érintett emberi méltóságával vagy magánszférájával. Másrészt, amennyiben igen, akkor vizsgálni kell, hogy sérül-e az emberi méltósághoz való jog, illetve a magánszférához való jog. Harmadrészt, esetről esetre kell vizsgálni, hogy a támadott határozat egyensúlyt teremt-e a konkrét esetben a szabad tájékoztatás és az emberi méltóságra visszavezethető képmásvédelem eltérő szempontjai között. Negyedrészt a mérlegelés során vizsgálni kell, hogy a képmás közzététele öncélú volt-e. Az Alkotmánybíróság szerint tehát a „képmásvédelem" csak akkor lehet a sajtószabadság valós korlátja, ha a képmás közzététele - a felismerhetővé váláson túlmutatóan - valamilyen alapjog sérelmét (különösen az emberi méltóság vagy a magánélethez való jog megsértését) vagy más alkotmányos érték sérelmét okozza. Külön nevesített alapjog hiányában a közhatalmat gyakorló személyek e tevékenységük során tűrni kötelesek képmásuk közzétételét.

A fénykép- és videófelvétel készítése tekintetében a szólás- és sajtószabadság gyakorlásának mércéi eltérnek egyfelől a bírósági tárgyalóterem és tárgyalás, másfelől az egyéb helyszínek és ott zajló közéleti események esetén. A tárgyalás nyilvánossága a tárgyalóterem nyilvánosságát, a bírósági eljárás és döntés figyelemmel követhetősé- 
gét jelenti. Alapvető indoka nem a közéleti vita általános információs érdeke, hanem az eljárásban érintettek védelme azzal, hogy jogaikról a bíróság a tárgyalás nyilvánosságának színe előtt döntsön. A tárgyalás nyilvánossága nem jelent sajtónyilvánosságot. Az igazságszolgáltatás függetlensége és a tárgyalás rendje olyan alkotmányos értékek, amelyek megvalósulása érdekében korlátozni lehet a sajtó tevékenységét, így ezen belül azt is, hogy kiknek a képmását teszik közzé.

Bár a tárgyalás rendje és az igazságszolgáltatás függetlensége olyan alkotmányos értékek, amelyek általánosságban alapot adnak a sajtószabadság korlátozására, ez nem jelenti azt, hogy a sajtó tevékenysége teljesen korlátozható lenne a bírósági tárgyaláson. Esetről esetre vizsgálva kell a bíróságoknak és végső soron az Alkotmánybíróságnak állást foglalnia arról, hogy a sajtó szabadságának védelmi körébe tartozó képi tudósítás lehetőségének biztosításához vagy annak korlátozásához fűződik-e erősebb alkotmányos érdek.

A tárgyalás vezetése a bíró feladata. Elsődlegesen a bíró tudja megítélni, hogy az adott tárgyaláson a sajtószabadság gyakorlása mennyiben alkalmas az igazságszolgáltatás rendjének, a bíró függetlenségének a megzavarására. Ha a tárgyalást vezető bíró szerint a zavaró körülmény fennáll, akkor sem jelenti ez automatikusan a sajtószabadság kizártságát, azt viszont igen, hogy mérlegelni kell, hogy a sajtószabadság gyakorlásához vagy korlátozásához füződik-e erősebb alkotmányos érdek.

Amennyiben valamely per közvetlen érintettjei nem kifogásolják a média tudósítását (ideértve a képi tudósítást is), akkor más személyek az igazságszolgáltatás rendjére hivatkozással nem kifogásolhatják a sajtószabadság gyakorlását. Jelen esetben a bíró nem zárta ki a nyilvánosságot (és ezzel a sajtót) a tárgyalásról és a per tárgya közérdeklődésre számot adó ügy volt, így az Alaptörvény IX. cikkére hivatkozással a sajtó szabadon közzéteheti a közhatalmat gyakorló személyek képmását. Ilyenkor is feltétel azonban, hogy a megjelenítés nem sértheti az emberi méltóságot.

Az Alkotmánybíróság - a fentiek alapján - a támadott ítéletet megsemmisítette, mivel az az Alaptörvény IX. cikk (2) bekezdésében garantált sajtószabadságot sértette.

2. A magánélet védelméhez való jog és a sajtószabadság ütközésének kérdésében a közhatalommal nem rendelkezö, de a politikai életre hatással bíró személyek magánélete sem zárható ki teljes mértékben a közérdeklödésből, különösen, ha ez a nyilvánosság elött zajlik, feltéve, hogy az erröl készült tudósítás a közéleti vitához hozzájárul, és nem sérti az érintett jó hírnevét vagy becsületét.

A 26/2019. (VII. 23.) AB határozat is a sajtó szabadságát védi, a közszereplőkre vonatkozó korábban kidolgozott mércét kiterjesztve a közhatalommal nem rendelkező, de politikai életre hatással bíró személyekre.

2.1. Az indítványozó alkotmányjogi panaszában azt kérte, hogy az Alkotmánybíróság állapítsa meg a Fővárosi Ítélőtábla ítéletének alaptörvény-ellenességét, és semmisítse meg azt. Az indítványozó szerint az ítélet ellentétes az Alaptörvény II. cikkében rögzí- 
tett emberi méltósághoz való joggal, valamint a VI. cikk (1) bekezdése szerinti magánélet tiszteletben tartásához füződő alapvető joggal.

Az indítványra okot adó ügyben egy internetes honlap közzétett egy cikket, amelyben az indítványozó külföldi nyaralásáról írt, és a cikkhez az indítványozóról több kép- és videófelvételt használt fel. Az indítványozó előadta, hogy sem a felvételek felhasználásához, sem azok közzétételéhez nem járult hozzá.

Az indítványozó keresetet terjesztett elő a sajtótermék kiadójával szemben, kérve a képmáshoz való joga megsértésének a megállapítását, az internetes sajtótermék kötelezését a jogsértés abbahagyására, a megállapított jogsértések közlésére és nyilvános bocsánatkérésre. Az internetes sajtótermék kiadója azzal érvelt, hogy az indítványozóról egy olyan szórakozóhelyen készült kép, ahova csak jeggyel lehetett bemenni, és a jegyértékesítés általános szerződési feltételei szerint a jegy vásárlója hozzájárul ahhoz, hogy reklámcélra a személyére is kiterjedő felvétel készüljön, és azt a szórakozóhely a saját tevékenysége során felhasználja. Az alperes másodlagosan azzal érvelt, hogy az indítványozó állítólag kormányzati tanácsadóként működik, rendszeresen feltűnik politikai vezetők, kormányhoz közel álló személyek társaságában, és ebből következően a jövedelmi helyzetére utaló, életmódjával kapcsolatos információ a közvélemény érdeklődésére is számot tart.

Az elsőfokú bíróság elfogadta az alperesnek azt az érvelését, hogy az indítványozó életvitelére vonatkozó információ nyilvánosság elé tárása közérdek, ezért a keresetet elutasította. Az indítványozó fellebbezése folytán eljáró Fővárosi Îtélőtábla az elsőfokú bíróság ítéletét eltérő indokolással helybenhagyta. A másodfokon eljáró bíróság a döntését arra alapította, hogy az indítványozó nemcsak a képek elkészítéséhez, hanem azoknak a szórakozóhely reklámozása céljából történő felhasználásához is engedélyt adott. A bíróság továbbá nem tartotta az indítványozót olyan magánszemélynek, aki személyiségi jogvédelemre jogosult abban az esetben, ha magánéletével kapcsolatos információ jut a sajtó tudomására. Az indítványozó felülvizsgálati kérelmet nyújtott be a Kúriához, amely osztotta a Fővárosi Ítélőtábla álláspontját.

2.2. Alkotmányjogi panaszában az indítványozó hivatkozott arra, hogy egy fénykép média általi felhasználása általában a véleménynyilvánítás szabadságának oltalma alá tartozik, jelen esetben azonban a perben kifogásolt felvételek semmilyen „véleményt” nem közölnek, pusztán az indítványozó arcképét ábrázolják. Az indítvány szerint a képfelvételek (azok helyszíne, az azokon látható környezet) nem hordoznak olyan információt, amely a közérdekủ társadalmi vita lefolytatására alkalmas lenne. Azt is előadta, hogy soha nem jelent meg a nyilvánosság előtt, nem vállalt közszereplést. Személyét csupán a sajtó kapta fel, ez azonban nem lehet automatikusan velejárója személyiségi joga korlátozásának.

2.3. Az Alkotmánybíróság megállapította, hogy az ügy az Alaptörvény IX. cikkében biztosított véleménynyilvánítás jogának és az Alaptörvény VI. cikkében rögzített ma- 
gánszféra-védelemnek, valamint az Alaptörvény II. cikkében rögzített emberi méltóságnak alkotmányjogi jelentőségű kollízióját vetette föl.

2.4. Az Alkotmánybíróság ugyan támaszkodott a bíróságok által megállapított tényállásra (ennek hiányában nem is tudott volna döntést hozni), de hatásköre jelen ügyben sem terjedhetett ki annak felülbírálatára, hogy a bíróságok milyen tények alapján hoztak döntést, vagy hogy azokat miképp értékelték. Az Alkotmánybíróság feladata abban állt, hogy meghatározza: az indítványozónak a bíróságok döntése folytán sérült-e valamilyen Alaptörvényben nevesített, indítványban hivatkozott joga.

A bíróság által megállapított tényállás értelmében az alperes az indítványozó külföldi nyaralásáról, egy szórakozóhelyen való időtöltéséről jelentetett meg médiatartalmat, amelyhez a szórakozóhely promóciós videóját is megosztották.

Az Alkotmánybíróság elsőként azt vizsgálta, hogy a Kúria az alkotmányos értelmezési tartományon belül maradt-e akkor, amikor úgy foglalt állást, hogy az Alaptörvény IX. cikkének védelme kiterjed a konkrét esetben az indítványozó magánélete egy szeletének feltárására. Az Alaptörvény IX. cikk (2) bekezdése értelmében Magyarország elismeri és védi a sajtó szabadságát és sokszínűségét. Az Alaptörvény IX. cikk (2) bekezdése a sajtószabadságot a demokratikus közvélemény kialakulásához szükséges szabad tájékoztatás garanciájának tekinti. Ez a tájékoztatás a „demokratikus közvélemény" információs érdekét szolgálja: azt, hogy a közvélemény a számára releváns tényekről, eseményekről adatot, tájékoztatást, illetve ezzel összefüggő véleményt kapjon.

Kitüntetett jellege ellenére sem tekinthető azonban a sajtószabadság korlátlannak vagy korlátozhatatlannak. Az Alaptörvény IX. cikk (4) bekezdése szerint a véleménynyilvánítás nem sértheti az emberi méltóságot. A rendszertani értelmezésből, a véleménynyilvánítási szabadság és a sajtószabadság tartalmi összefüggéséből az következik, hogy ez a korlát a sajtószabadság tekintetében is irányadó.

A közéleti viták szabadsága és sokszínűsége nélkül nincsen szabad közvélemény és nincsen demokratikus jogállam. Az Alkotmánybíróság gyakorlatában a politikai jellegű közéleti szólások erősebb védelmet élveznek, és korlátozásuk csak a legszükebb körben nyerhet igazolást. A közéleti viták lényegi részét jelentik a közélet alakítóinak tevékenységét, nézeteit, hitelességét érintő megnyilvánulások. A közéleti vita nemcsak a szűkebb értelemben vett politikai vitát jelenti, hanem valamennyi társadalmi jelentőségü kérdés megvitatása is ebbe a körbe sorolandó. Alkotmányosan az vizsgálandó, hogy az adott közlésnek van-e bármilyen köze egy adott közéleti vitához, illetve közszerepléshez. Amennyiben igen, akkor csak a kivételes esetekben korlátozható a sajtószabadság.

Egy természetes személy életkörülményei, ideértve azt is, hogy hol nyaral és milyen szórakozóhelyre jár, az Alaptörvényben védett magánéletének részei. A bírósági döntések is egyhangúan jutottak arra a következtetésre, hogy az internetes honlap az indítványozó magánéletére vonatkozó tájékoztatást közölt és arról osztott meg korábban a nyilvánosság felé közvetített képet. Jelen ügyben azonban a Kúria helyesen 
mutatott rá, hogy a magánélettel kapcsolatos információ megosztása (többszörözése) a közügyek vitatásához hozzájárul. A puszta információs érdek (a közvélemény kíváncsisága, hogy az illető hol nyaral) nem szolgálhatna alapot az emberi méltóság és a magánszférához való jog korlátozására, a demokratikus vita lehetőségének biztosítása viszont igen.

A sajtószabadság fokozottabb védelme nem korlátozódik a közhatalmat gyakorló személyek tevékenységének bemutatására; a közügyek szabad megvitatásához hozzájárulhat olyan személyek magatartása is, akik egyébként közhatalmat nem gyakorolnak. A megváltozott társadalmi viszonyok, különösen a telekommunikáció terjedése révén a közszereplői kör kiszélesedett. Így olyan személyeknek is lehetőségük nyílik egy-egy közéleti vita aktív alakítójává válni, akik korábban - státuszuk alapján - nem tartoztak a közszereplő fogalmi körébe. Ezek a személyek az úgynevezett kivételes közszereplők. Ebbe a kategóriába nemcsak a médiaszereplők tartoznak, hanem azok is, akik hatással vannak politikai döntésekre és az államélet alakulására, vagy a médiában betöltött tulajdonosi szerepükön keresztül a közvéleményre. Az indítványozó kivételes közszereplői státusának igazolása vagy cáfolata pedig a közügyek szabad megvitatásának része. Az indítványozó társadalmi szerepe jelen ügyben olyan körülmény, ami „közéleti vita”, így e vonatkozásban a sajtószabadság korlátozása csak kivételesen lenne igazolható.

Az emberi méltóság és a magánszféra védelmét a kivételes közszereplők is élvezik. Az általuk nyilvánosságra nem hozott, közügyekkel összefüggést nem mutató tevékenységüket (magánéletük védett részét) a média nem hozhatja nyilvánosságra a sajtószabadságra hivatkozással. Amennyiben viszont a közéleti vitának épp a magánélet egy szelete a tárgya, akkor - szorosan ebben a körben - a véleménynyilvánítás szabadságát kell előnyben részesíteni. Ezekre tekintettel az Alkotmánybíróság megállapította: a Kúria nem lépte túl az értelmezés alkotmányos kereteit, amikor úgy foglalt állást, hogy az indítványozóra vonatkozó közéleti közléseket „a véleménynyilvánítás szabadságához füződő jog legmagasabb szintü védelme illeti meg”.

Az Alkotmánybíróságnak azt is értékelnie kellett, hogy az eredetileg marketingcélból készített - és így a csekélyebb alkotmányos védelmet élvező „kereskedelmi szólás" által védett - magánéletet ábrázoló képet az eredetitől eltérő céllal, más médiafogyasztók számára tették elérhetővé. Általánosságban kijelenthető, hogy ha valaki a magánéletének valamely elemét önként tárja fel a médiának vagy egyéb módon önként nyilvánosságra hozza, akkor ezen információ vonatkozásában már nem hivatkozhat magánszférájának védelmére. A Kúria kellően bizonyítottnak találta, hogy az indítványozó hozzájárult a róla szóló kép elkészítéséhez és megosztásához, így ezt az Alkotmánybíróság is irányadónak tekintette. Az indítványozó nem hivatkozhat tehát a magánszféra sérelmére a róla promóciós célból készült kép elkészítésével és megosztásával kapcsolatban, ha ehhez előzetesen hozzájárult.

Kétségtelen, hogy az eredetileg „kereskedelmi szólásnak” minősülő médiatartalom az alperes közzététele folytán közéleti vitává, így „politikai szólássá” vált. Ez azonban nem oka a védelmi szint csökkentésének. Épp ellenkezőleg: közéleti vita lévén 
az Alaptörvény IX. cikkéből eredő jogosultságokat még az eredeti védelemnél is jobban kell védeni. Mindaddig, amíg a sajtószabadság gyakorlása nem sért más alapjogot, addig megjelenési formájától függetlenül az Alaptörvény IX. cikkének védelmét élvezi.

Az indítványozó nem állította, hogy a bírói döntések sértették volna a jó hírnevét vagy becsületét. A közlés nem volt dehonesztáló, nem tüntette fel negatív színben az indítványozót. Erre tekintettel jelen esetben a bíróság helyesen mérlegelte, hogy önmagában annak a ténynek a közlése és képi bemutatása, hogy az indítványozó a nyaralása során egy szórakozóhelyen járt, nem jelenti a magánélethez való jog vagy az emberi méltóság aránytalan korlátozását.

Az Alkotmánybíróság az Alaptörvény VI. cikkének (1) bekezdésben foglalt magánélet védelméhez való jog és a IX. cikk (2) bekezdésben foglalt sajtószabadság kollíziójának kérdésében elvi éllel mutatott rá, hogy a közhatalommal nem rendelkező, de a politikai életre hatással bíró személyek magánélete sem zárható ki teljes mértékben a közérdeklődésből, különösen, ha ez a nyilvánosság előtt zajlik, feltéve, hogy az erről készült tudósítás a közéleti vitához hozzájárul, és nem sérti az érintett jó hírnevét vagy becsületét.

Az Alkotmánybíróság tehát a sajtó szabadságát védve az alkotmányjogi panaszt elutasította.

3. Nem lehet a terheltre róni a hatóságok, biróságok mulasztásának vagy a hatóságok, biróságok által elkövetett hibáknak a következményeit, vagyis az eljárás megismétlését.

A 20/2019. (VI. 26.) AB határozatban - bírói kezdeményezés alapján az Alkotmánybíróság mulasztásban megnyilvánuló alaptörvény-ellenesség megállapítása mellett egy jogállami büntetőeljárás-jogi garancia érvényesítésére hívta fel a jogalkotót.

3.1. A Nyíregyházi Törvényszék bírója az előtte folyamatban lévő eljárást felfüggesztette, és egyidejűleg bírói kezdeményezéssel fordult az Alkotmánybírósághoz a büntetőeljárásról szóló 2017. évi XC. törvény (Be.) 631. \$-át érintően.

Az indítvány alapjául szolgáló büntetőeljárás több terhelt ellen közokirat-hamisítás büntette miatt volt folyamatban. Az indítványozó bíró szerint az alapeljárásban a járásbíróság a II. rendű vádlott kérelmére a régi Be. alapján védőt rendelt ki, akinek a részvétele az eljárásban azt követően kötelező. Ezen a körülményen az időközben hatályba lépett Be. sem változtatott. A védő így a folyamatban lévő másodfokú eljárásban is részt vesz, és a megjelenésével összefüggésben bűnügyi költség merül fel. Ezen költség viseléséről az egyéb bűnügyi költséggel együtt az eljáró másodfokú bíróságnak ügydöntő határozatában a Be. szabályai alapján kell majd rendelkeznie. Az indítványozó bíró szerint ugyanakkor az ennek során alkalmazandó Be. 631. \$-a több okból is ellentétes az Alaptörvénnyel. Az indítványozó szerint a Be. 631. \$-ának nyelvtani értelmezése és alkalmazása azzal a következménnyel jár, hogy egy esetleges harmadfokú eljárásban felmerült bűnügyi költséget - ellentétesen a Be. másik 
rendelkezéseivel - minden esetben az államnak kellene viselnie. A jogszabályon belül ezért a bűnügyi költségre vonatkozó, jelzett jogszabályi rendelkezések között normakollízió áll fenn, és az ellentmondás rendszertani értelmezéssel sem feloldható. Az indítványozó tehát a fentiekre figyelemmel annak megállapítását kérte, hogy az előtte folyamatban lévő ügyben alkalmazandó szabály alaptörvény-ellenes. Álláspontja szerint ugyanis a hivatkozott rendelkezés nem tesz eleget az Alaptörvény B) cikk (1) bekezdéséből fakadó jogállamisági követelményeknek.

3.2. Az Alkotmánybíróság kiemelte, hogy a támadott és azzal összefüggésben felhívott jogszabályi rendelkezések alkalmazása következtében a bíróságnak a megismételt másodfokú eljárásban a vádlottat kell köteleznie a bünügyi költség megfizetésére, amennyiben a felelősségét megállapítják. A költségek vagy egy részük megfizetése alól a bíróság a terheltet legfeljebb méltányosságból mentesítheti. Az indítványozó kifogása szerint a szabályozás következtében a bünügyi költség viselésének a meghatározásakor a bíróság nem lehet tekintettel arra, hogy a megismételt eljárás folytatása az alapeljárásban a bíróság által elkövetett eljárási szabályszegés miatt vált szükségessé. Ennek következtében pedig a szabályozás ellentétes a jogbiztonságból levezethető azon elvárással, hogy a bíróság a terheltet mentesítse azon bünügyi költség viselése alól, amely annak folytán merült fel, hogy az eljárást meg kellett ismételni.

Az Alkotmánybíróság korábbi határozataiban is következetesen képviselte azt az álláspontot, hogy a jogállamban a bünüldözésnek szigorú anyagi jogi és eljárási jogi korlátok között kell folynia, a bűnüldözés sikertelenségének kockázatát azonban az állam viseli. Az Alkotmánybíróság értelmezésében a bizonyítás sikertelensége éppúgy az állam kockázati körébe tartozik, mint az eljárás során elkövetett hibák, sőt az eljárást akadályozó bármely körülmény is, amely folytán a büntetőeljárás ideális célja, az igazságos és célját betöltő büntetés kiszabása nem teljesülhetett. Sem a büntetőpolitika változása, sem az eljáró hatóságok mulasztása vagy hibája nem eshet az elkövető terhére.

Az Alkotmánybíróság a szabályozás áttekintése eredményeként megállapította, hogy a büntetőeljárások megismétlésének az oka valamennyi esetben a törvényi előírások megsértése. A törvényi előírások betartását a büntetőeljárásban részt vevő hatóságoknak, bíróságoknak kell felügyelniük. Így szabályszegés kizárólag valamely hatóság mulasztásának vagy hibájának lehet az eredménye. A hatóságok, bíróságok mulasztásának vagy a hatóságok, bíróságok által elkövetett hibának a következményeit, vagyis az eljárás megismétlését az Alaptörvény B) cikk (1) bekezdéséből fakadó követelmények értelmében nem lehet a terheltre róni. A bűnüldözés sikertelenségének a kockázatát - az Alkotmánybíróság következetes gyakorlata értelmében - ugyanis az állam viseli. Az eljárás során a hatóságok részéről akár szándékosan, akár véletlenül elkövetett hibák ilyen kockázati tényezőnek minősülnek. A jogállam értékrendje szerint e kockázati tényezők következményeinek a terheltre történő áthárítása kizárt. Ezért függetlenül attól, hogy a büntetőeljárás befejezésekor a terhelt felelősségét meg- 
állapítják-e, vagy sem, az eljárás szükséges megismétléséből fakadó költségeket az államnak és sosem a terheltnek kell viselni.

Az Alkotmánybíróság megállapította, hogy a jogállamiság követelményéből levezethető azon szabályozás igénye, amelynek értelmében a büntetőeljárás megismételt eljárási szakaszaiban a terhelt nem kötelezhető annak a bünügyi költségnek a viselésére, amely annak folytán merült fel, hogy az eljárást meg kellett ismételni. Az Alkotmánybíróság úgy ítélte meg, hogy ez a követelmény nem csupán a másodfokú megismételt eljárásban, hanem az elsőfokú eljárás megismétlése esetén is érvényesítendő. A szabályozás alaptörvény-ellenessége nem a Be. 631. \$-ának a szabályozásából, hanem abból fakad, hogy a Be. a bünügyi költség perbeli megállapítására vonatkozó, egybevetett és értelmezett szabályrendszere sem tartalmaz olyan garanciális jogszabályi rendelkezést, amely a bűnügyi költség viselésére a megismételt elsőés másodfokú eljárásban irányadó szabályozást a jogállamiságból fakadó követelményekkel összhangba hozná.

3.3. A szabályozás hiányossága miatt úgy ítélte meg, hogy az Alaptörvénnyel való összhang helyreállítása nem a vitatott rendelkezés megsemmisítését, inkább a hatályos szöveg kiegészítését teszi szükségessé. Ilyen módon biztosíthatóvá válik, hogy a bűnüldözés sikertelenségének kockázatát a bünügyi költséggel összefüggésben az állam viselje. Az Alkotmánybíróság a fentiek alapján hivatalból eljárva megállapította, hogy az Országgyủlés mulasztásban megnyilvánuló alaptörvény-ellenességet idézett elő azáltal, hogy a Be. megismételt eljárásra irányadó szabályaiban nem szabályozta az Alaptörvény B) cikk (1) bekezdéséből fakadó követelményeknek megfelelően a bünügyi költség viselését, és felhívta az Országgyủlést, hogy jogalkotói feladatának 2019. szeptember 30-ig tegyen eleget.

4. Közszereplő bírálata közösségi oldalon, a valóság bizonyitása garanciáinak érvényesülése

A 29/2019. (XI. 4.) AB határozatban az Alkotmánybíróság a közszereplők bírálhatósága szempontjából fontos, a szólásszabadságot védő határozatot hozott.

Az Alkotmánybíróság alkotmányjogi panasz indítvány alapján megsemmisítette a Kúria becsületsértés vétsége és más bűncselekmények tárgyában hozott végzését, illetve a Miskolci Törvényszék és a Tiszaújvárosi Járásbíróság ítéleteit.

4.1. Az indítványozó korábban egy internetes közösségi portálon a saját fiókjához tartozó üzenőfalon több esetben a település jegyzőjét bírálta. Később, egy helyi közmeghallgatáson nyilvánosság előtt azt állította, hogy a sértett jegyző őt kétszer is feljelentette, a rendőrségen pedig hamis tanúvallomást tett. A sértett feljelentése nyomán eljárt első- és másodfokú bíróság becsületsértés vétsége és folytatólagosan elkövetett rágalmazás vétsége tárgyában megállapították az indítványozó bűnösségét és halmazati büntetésként pénzbüntetést szabtak ki rá. A Kúria az ítéleteket hatályában fenntartotta. 
Az Alkotmánybíróság az indítványozó egy korábbi panasza alapján a Kúria helybenhagyó végzését a 3263/2018. (VII. 20.) AB határozatban (Abh.) megsemmisítette, mivel az sértette az indítványozó véleménynyilvánítási szabadságát. Bár az Abh. a Kúria felülvizsgálati eljárás keretében hozott, az első- és másodfokú bírói döntéseket hatályában fenntartó végzését megsemmisítette, a Kúria a felülvizsgálati eljárást ismételten lefolytatta, és a támadott döntése a jogerős ítéletet ismét hatályában fenntartotta.

A Kúria a támadott végzésében - a korábban megsemmisített határozatával szemben - nem azt az álláspontot hagyta helyben, hogy nincs helye a valóság bizonyításának, hanem arra hivatkozott, hogy a becsület csorbítására alkalmas tény valóságát a bizonyítási eljárás keretében a szükséges körben megvizsgálta, és a tény nem bizonyult valósnak. A Kúria szerint nincs szükség a valóság bizonyításának alakszerű elrendelésére, ha a bírósági eljárás egyebekben vizsgálta az állítás valóságát.

Az indítványozó utóbbi végzéssel szemben alkotmányjogi panaszt terjesztett elő.

Álláspontja szerint a Kúria támadott döntése - az Alkotmánybíróság korábbi határozatában foglaltak szerint - továbbra is sérti a véleménynyilvánítás szabadságához való alapjogát.

Az Alkotmánybíróságnak az Alaptörvényen alapuló hatásköre, hogy megállapítsa: egy bírói döntés sértette-e az indítványozó Alaptörvényen alapuló jogát. Ahogy az Alkotmánybíróság nem kérdőjelezheti meg a bíróság által megállapított tényállást, vagy azt, hogy egy meghatározott cselekményt milyen jogszabály alapján kell megítélni, ugyanúgy az általános hatáskörủ bíróságnak sincs hatásköre annak megállapítására, hogy valamely személy magatartását az Alaptörvény nem védi, ha az Alkotmánybíróság a konkrét ügyben (ugyanazon személy ugyanazon magatartása kapcsán) ezzel ellentétesen határozott. Ez a megközelítés áll összhangban azzal, hogy a bírósági szervezet legfőbb szerve a Kúria, az Alaptörvény védelmének a legfőbb szerve viszont az Alkotmánybíróság.

Egy megismételt eljárásban hozott döntés tartalmát az Alkotmánybíróság akkor teszi ismét érdemi vizsgálat tárgyává, ha az az előző döntéshez képest új alkotmányos összefüggésre mutat rá, amellyel az Alkotmánybíróság korábbi döntése nem foglalkozott.

A támadott döntés abban különbözik az Abh.-ban elbírált döntéstől, hogy a Kúria nem azt az álláspontot hagyta helyben, hogy nincs helye a valóság bizonyításának, hanem arra hivatkozott, hogy a becsület csorbítására alkalmas tény valóságát a bizonyítási eljárás keretében a szükséges körben megvizsgálta, és a tény nem bizonyult valósnak. A Kúria álláspontja szerint nincs szükség a valóság bizonyításának alakszerű elrendelésére, ha a bírósági eljárás egyebekben vizsgálta az állítás valóságát.

Az Abh. korábban arra tekintettel tartotta az ott vizsgált bírói döntést alaptörvényellenesnek, hogy az nem rögzítette, hogy a sértettre vonatkozó tényállítás miért került ki a közügyek vitájának a köréből. Az Abh.-ból az következik, hogy a terheltnek a közügyek vitatása során tett, közszereplő becsületét sértő tényállítás kapcsán lehetőséget kell adni arra, hogy a valóságot bizonyítsa. A „bizonyítás” során a terheltnek eljárási 
jogosultságai vannak, az eljárási cselekményekre észrevételeket, indítványokat tehet, amelyek befolyásolhatják a végső bírósági döntést. Mindezeket nem pótolja, ha felülvizsgálati eljárás keretében (amikor új bizonyítékok felvételére nincs mód) a Kúria azt a következtetést vonja le, hogy a terhelti állítás valótlanságát már megállapították.

Az Alaptörvény IX. cikke a tényállításokat is védi. A véleménynyilvánítás szabadságának egyik garanciája, hogy a bíróságok az alapeljárás keretében is vizsgálják a terhelti állítás valóságtartalmát, és a terheltnek formalizált keretek között van lehetősége eljárási jogainak érvényesítésére. Mivel erre a támadott döntés nem biztosított lehetőséget, az az Alaptörvény IX. cikk (1) bekezdésével ellentétes.

Az Alkotmánybíróság ismételten rámutatott, hogy az indítványozó kifejezéseit a véleménynyilvánítás szabadsága védte, a bírálat ugyanis nem sértette az érintett közszereplő emberi méltóságának lényegi magját. Az Alkotmánybíróság nem látta indokát annak, hogy korábbi álláspontjától eltérjen, ezért újra megállapította, hogy a Kúria hatályában fenntartott olyan bírósági döntéseket, amelyek az indítványozó védett véleménynyilvánítását büncselekménynek minősítették. Az Alkotmánybíróság hangsúlyozta: a véleménynyilvánítás szabadságának egyik garanciája, hogy a bíróságok az alapeljárás keretében is vizsgálják a terhelti állítás valóságtartalmát, és a terheltnek formalizált keretek között van lehetősége eljárási jogainak érvényesítésére. Mivel erre a támadott döntés nem biztosított lehetőséget, azt az Alkotmánybíróság - a korábban hozott ítéletekkel együtt - megsemmisítette.

5. Az Alaptörvényböl levezethetö, hogy a fegyelmi eljárás megszüntetése esetén, amenynyiben a fegyelmi felelösséget nem állapítják meg, a visszatartott távolléti dijat vissza kell fizetni.

Az Alkotmánybíróság a 3294/2019. (XI. 18.) AB határozatban megsemmisítette a Kúria visszatartott illetmény megfizetése tárgyában hozott ítéletét.

5.1. Az alkotmányjogi panasz alapjául szolgáló ügyben az indítványozó a rendőrkapitányságnál hivatásos szolgálatot teljesített. Egy éjszaka szolgálatteljesítés közben a fogdában fogadott egy embert, de nem észlelte, hogy nála tiltott tárgyak voltak. Miután az indítványozó ezt később felfedezte, elvette a fellelt tárgyakat, és utólag bevezette a letéti jegyzőkönyvbe. Az indítványozót az ügyészség hivatali visszaélés bűntettének megalapozott gyanúja miatt gyanúsítottként hallgatta ki, elrendelte a bünügyiőrizetbe-vételét. A büntetőeljárásra tekintettel a rendőrkapitány fegyelmi eljárást rendelt el, és az indítványozó szolgálati beosztásából való felfüggesztéséről, illetőleg távolléti díja 50\%-ának visszatartásáról rendelkezett. Később az indítványozóval szemben folyt összes büntetőeljárást megszüntették. Ezt követően az indítványozó szolgálati viszonyát munkáltatója felmentéssel megszüntette. A rendőrkapitány az indítványozóval szemben korábban indított fegyelmi eljárást megszüntette, azzal, hogy a visszatartott illetménye utólagos kifizetésének a szolgálati jogviszonyról szóló törvény alapján nincs helye. Az indítványozó a visszatartott illetmény kifizetésének 
megtagadását jogszerűtlennek tartotta, panasszal élt, de panaszát a megyei rendőrfőkapitány elutasította.

Az indítványozó bírósághoz fordult, a Közigazgatási és Munkaügyi Bíróság a keresetnek helyt adott, majd az ítéletet a Törvényszék helyben hagyta. Az alperes felülvizsgálati kérelme folytán eljárt Kúria a jogerős ítéletet hatályon kívül helyezte, az elsőfokú határozatot pedig megváltoztatta és az indítványozó keresetét elutasította. A Kúria indokolása szerint az indítványozó szolgálati viszonya egészségi állapotára tekintettel felmentéssel szűnt meg, ami a fegyelmi eljárás megszüntetését is maga után vonta, ezt viszont nem lehet a fegyelmi felmentéssel azonosítani, így a visszatartott illetmény kifizetésére sem kerülhetett sor. A Kúria ítélete szerint ugyanis a visszatartott illetmény kifizetésére kizárólag akkor van mód, ha a fegyelmi vagy büntetőeljárás felmentéssel zárul. Álláspontja szerint mivel az adott ügyben a fegyelmi eljárás nem felmentéssel zárult, az így megszüntetett fegyelmi eljárás esetén a visszatartott illetmény kifizetését nem teszi lehetővé.

5.2. Alkotmányjogi panaszában az indítványozó a hátrányos megkülönböztetés tilalmára és a tisztességes bírósági eljáráshoz való jog sérelmére hivatkozott. Azzal érvelt, hogy a Kúria határozata és a jogszabályi rendelkezések nem megfelelő alkalmazása folytán nem kerülhetett sor a visszatartott távolléti díja kifizetésére, annak ellenére, hogy vele szemben sem a büncselekmény elkövetését, sem a fegyelemsértést nem állapították meg. Szerinte ez hátrányos megkülönböztetését jelenti azokkal szemben, akiknek ugyan szintén felmentéssel szűnt meg a szolgálati viszonya, azonban az esetleges fegyelmi eljárás ellenük a felmentésük elött lezárult. A Kúria a jogalkotói céllal ellentétes határozatot hozott, és nem adott számot annak indokairól, hogy az ügyben releváns elvi döntést miért nem tartotta irányadónak.

5.3. Az Alkotmánybíróság a hátrányos megkülönböztetés tilalmával kapcsolatban rámutatott, hogy a Kúria a fegyelmi eljárásnak a szolgálati viszony megszünése folytán kötelező megszüntetése esetét azonos módon értékelte azokkal az attól különböző esetekkel, amikor a fegyelemsértés - érdemi vizsgálatot követő - megállapítására és szankció (valamely fegyelmi fenyítés) alkalmazására kerül sor. Tehát az indítványozó a Kúria ítélete folytán a fegyelemsértést elkövetőkkel került azonos csoportba, annak ellenére, hogy a két személyi kör heterogén. Vagyis - a Kúria érvelésével ellentétben - nem a fegyelmi eljárás megszüntetésének okai, hanem a fegyelmi felelősség megállapítása vagy annak hiánya határozzák meg a csoportképzés mércéjét, ennek folytán a visszatartott illetmény kifizethetőségét, vagyis a fegyelmi eljárás alá vont személy illetményhez való hozzájutását.

5.4. A fentiekre tekintettel az Alkotmánybíróság megállapította, hogy az indítványozónak a Kúria ítélete folytán a fegyelemsértést jogerősen elkövetett személyekkel azonosan való kezelése a hátrányos megkülönböztetés tilalmát sérti. 
A tisztességes eljáráshoz való jog sérelmével összefüggésben pedig az Alkotmánybíróság arra jutott, hogy a Kúria nem fejtette ki döntésének releváns indokait, vagyis nem tett eleget a bírói indokolással szemben támasztott követelménynek. Mindezekre tekintettel az Alkotmánybíróság a Kúria ítéletét megsemmisítette.

6. A diszkrimináció tilalmába ütközik és ezért alaptörvény-ellenes az az illetéktörvényi szabályozás, amelynek következtében az indítványozó jogkövetö magatartása ellenére hátrányosabb helyzetbe került, mint az, aki be sem fizette az illetékelöleget.

A 34/2019. (XI. 29.) AB határozatban az Alkotmánybíróság az illetékekről szóló törvény (Itv.) egy hatályon kívül helyezett rendelkezésének alaptörvény-ellenességét vizsgálta.

6.1. Az alkotmányjogi panasz alapjául szolgáló ügyben az indítványozó egy lakás építésére és vételére vonatkozó adásvételi szerződést kötött az eladó gazdasági társasággal. A kiszabott illetékelőleg-fizetési kötelezettségének az indítványozó eleget tett, azonban az eladó működési körében felmerült problémák miatt az építkezés leállt, az eladó cégét felszámolták, így végül az indítványozó a lakáson nem szerzett tulajdont. Ennek következtében az indítványozó illetékelőleg-visszatérítési kérelmet terjesztett elő az adóhatóságnál, amelyben arra való tekintettel kérte a visszterhes vagyonátruházási illetékelőleg visszautalását, hogy sosem szerzett tulajdonjogot. Az Itv. akkor hatályos rendelkezéseiből az következett, hogy az illetékelőleg megfizetésétől számított öt éven belül lett volna lehetősége az indítványozónak a két részletben befizetett összeg visszatérítésének igénylésére. Ezek objektív határidők, amelyeken túl a kérelem nem teljesíthető. Kérelmét tehát az adóhatóság - elévülésre hivatkozással elutasította. Az indítványozó kereseti kérelmet terjesztett elő a Fővárosi Közigazgatási és Munkaügyi Bíróságnál (KMB), amely helybenhagyta az adóhatóság első- és másodfokon hozott döntéseit, arra tekintettel, hogy az illetékekről szóló törvény vonatkozó rendelkezéseinek megfeleltek.

Az indítványozó ezt követően felülvizsgálati kérelemmel fordult a Kúriához, amelyben elsődlegesen a KMB ítéletének hatályon kívül helyezését kérte annak jogszabálysértő volta miatt. Másodsorban indítványozta, hogy a Kúria kezdeményezzen egyedi normakontroll eljárást az Alkotmánybíróságnál az Itv. sérelmezett rendelkezései tekintetében. A Kúria a KMB ítéletét hatályában fenntartotta és az Alaptörvény 37. cikk (4) bekezdésében lefektetett, költségvetési, adó-, illetve illetékek szabályozására vonatkozó alkotmánybírósági hatásköri korlátozás miatt nem kezdeményezte az alkotmányossági felülvizsgálatot.

6.2. Az indítványozó alkotmányjogi panasszal fordult az Alkotmánybírósághoz. Az indítványban előadta, hogy az Alaptörvény XV. cikk (1) bekezdésének, azaz a hátrányos megkülönböztetés tilalmának sérelme áll fenn a szabályozás következtében. A törvény akkor hatályos rendelkezése szerint ugyanis a meg nem fizetett illeték bármikor törölhető volt, a megfizetett illeték ezzel szemben azonban csak a megfizetést köve- 
tő öt éven belül volt visszatéríthető, így hátrányosabban alakult az illeték visszatérítési igénye azoknak, akik jogszabálykövető eljárást tanúsítva megfizették a kiszabott és esedékes illetéket, mint azoknak, akik az illetékfizetési kötelezettségüket elmulasztották teljesíteni. A korábbi szabályozás időközben megváltozott, hiszen 2013. január 1-jétől a megfizetett, valamint a meg nem fizetett illeték visszatérítésének határidejére is egységesen az adózás rendjéről szóló törvény (a továbbiakban: Art.) elévülésre vonatkozó szabályait kell alkalmazni. A hátrányos megkülönböztetést tehát a jogalkotó is felismerte és ezért meg is szüntette. Az indítványozó ügyében azonban a korábbi szabályokat kellett alkalmazni.

Az indítványozó a tulajdonhoz való joga sérelme mellett kiemelte, hogy esetében konkrétan is tetten érhető a diszkrimináció, mivel az eladó több olyan magánszemélylyel is kötött adásvételi szerződést, akik az illetékelőleget nem fizették meg, és végül a szabályozásnak köszönhetően illetékfizetési kötelezettségüket törölték, valamint olyanokkal is, akik az illetékelőleget csak többéves késedelemmel fizették meg, és így számukra azt az adóhatóság visszatérítette.

Az indítványozó hangsúlyozta, hogy amennyiben az adóhatóság határozataiban foglaltaknak eleget nem téve, az illetékelőleget nem vagy csak jelentős késedelemmel fizette volna meg, abban az esetben semmilyen jogvita nem alakult volna ki, hiszen az adóhatóság illetékfizetési kötelezettségét törölte volna vagy a már teljesített fizetést visszatérítette volna.

6.3. Mivel a támadott szabályozás az illetékekről szóló törvény egyik rendelkezése, az Alkotmánybíróságnak elsőként vizsgálnia kellett, hogy az Alkotmánybíróság eljárása a hatáskört korlátozó szabály [Alaptörvény 37. cikk (4) bekezdés] alkalmazási hatálya alá tartozik-e a támadott jogszabályi rendelkezések tekintetében.

Az Alkotmánybíróság a jelen ügyben is hangsúlyozta, hogy az alkotmányossági felülvizsgálatot korlátozó szabály alkalmazási hatályát megszorítóan értelmezi, ez a megközelítés áll ugyanis összhangban az Alkotmánybíróság alkotmányvédelmi funkciójával, amely abban az alaptörvényi szabályban gyökerezik, miszerint „[a]z Alkotmánybíróság az Alaptörvény védelmének legfőbb szerve”. A támadott rendelkezések közül az egyik a hatásköri korlátozás alá esik, ezért azt az Alkotmánybíróság nem vizsgálhatta. A másik, elévülésre vonatkozó szabályt azonban igen. Az előbbiek alapján az Alkotmánybíróság megállapította, hogy az nem tartalmazott anyagi fizetési kötelezettséget, és törvényi tényállási elemet sem rejtett magában. Tartalmilag egy jogvesztő határidőt fektetett le a megfizetett illetékelőleg visszatérítésére. Ezért nem esik a korlátozó szabály hatálya alá, tehát az Alkotmánybíróság vizsgálhatja a tulajdonhoz való joggal és a diszkrimináció tilalmával összefüggésben is. Hangsúlyozandó, hogy nem az előleg - jelen esetben az illetékelőleg -, mint az adójogban alkalmazott jogintézmény volt tehát alkotmányossági vizsgálat tárgya.

6.4. Az Alkotmánybíróság vizsgálata során abból indult ki, hogy a jogalkotót széles mozgástér illeti meg a visszatérítési kérelem időbeli korlátjának meghatározása tekin- 
tetében. A jogszabályban lefektetett objektív határidő csak szélsőséges esetben tekinthető önkényesnek a közpénzügyi jogviszonyokban.

Az Alkotmánybíróság megállapította, hogy a sérelmezett szabályozás észszerű indok nélkül tett különbséget a visszatérítésre jogosult alanyok homogén csoportján belül. A már hatálytalan szabály azért lépte túl a jogalkotó számára mindig is nyitva álló széles mérlegelési mozgásteret, mert egyszerre volt megállapítható, hogy a határidő az igénylési lehetőség megnyílta előtt vette kezdetét, figyelmen kívül hagyta az illetékjogviszony lényeges sajátosságát, megbontotta e jogviszony felei közti egyensúlyt, mindeközben a kiszabott illetékelőleg visszatérítésére jogosult alany hatókörén kívül állt a felszámolási eljárás befejezésének időpontja. Ezek miatt a támadott rendelkezés szélsőséges volt.

Miután a sérelmezett eljárási szabály nem elégíti ki a rá vonatkozó speciális alkotmányossági követelményeket, az Alkotmánybíróság arra a következtetésre jutott, hogy a törvényhozó az illetékelőleg-visszatérítésre jogosult homogén személyi kör egy részét hátrányosabb helyzetbe hozta, mint a másikat, és ennek nincs a tárgyilagos mérlegelés szerinti észszerű indoka. Ezért az Alkotmánybíróság megállapította, hogy az illetékekről szóló törvény 2012. december 31. napjáig hatályos „a megfizetett illeték a megfizetést követő öt éven belül téríthető vissza" tagmondata alaptörvény-ellenes volt, valamint megtiltotta a folyamatban lévő illetékelőleg visszafizetésével kapcsolatos ügyekben való alkalmazását. 